\title{
Pengaruh Agen Hayati terhadap Wereng Batang Cokelat (Nillavarpata lugens Stall) Pada Tanaman Padi
}

\author{
Teguh Aristyawan, Ruswadi Muchtar dan Diah Meidiantie \\ Program Studi Agroteknologi Fakultas Pertanian Universitas Respati Indonesia Jakarta \\ Email: ruswadi_muchtar@yahoo.co.id
}

\begin{abstract}
ABSTRAK
Wereng batang coklat merupakan hama utama pada tanaman padi. Pada umumnya dikendalikan menggunakan insektisida kimia namun berakibat buruk terhadap lingkungan dan kesehatan. Alternatif insektisida yang direkomendasikan untuk mengendalikan hama tanaman adalah agen hayati Beauvaria bassiana. Tujuan penelitian adalah mengetahui efektivitas Beauvaria bassiana sebagai insektisida hayati terhadap mortalitas wereng batang coklat pada tanaman padi. Metode penelitian menggunakan rancangan acak lengkap (RAL) yang terdiri atas 5 perlakuan terdiri dari $\quad A=$ kontrol (1 liter air), $B=1$ liter air $+10^{1} / \mathrm{ml}$ spora Beauvaria bassiana, $C=1$ liter air $+10^{2} / \mathrm{ml}$ spora Beauvaria bassiana, $D=1$ liter air $+10^{4} / \mathrm{ml}$ spora Beauvaria bassiana, $\mathrm{E}=1$ liter air $+10^{6} / \mathrm{ml}$ spora Beauvaria bassiana. Perlakuan di ulang sebanyak 6 ulangan sehingga terdapat 30 unit percobaan. Hasil penelitian menunjukkan bahwa perlakuan 1 liter air $+10^{6} \mathrm{ml}$ spora Beauvaria bassiana mengghasilkan mortalitas batang coklat yang paling tinggi dan berpengaruh nyata dengan perlakuan lainnya.
\end{abstract}

Kata Kunci : Hama tanaman, Wereng batang coklat, Agen hayati, Beauvaria bassiana

\begin{abstract}
Brown stalks are the main pest in rice plants. Generally controlled using chemical insecticides but have a negative impact on the environment and health. An alternative insecticide recommended for controlling plant pests is the Beauvaria bassiana biological agent. The purpose of this study was to determine the effectiveness of Beauvaria bassiana as a biological insecticide on the mortality of brown plant hopper on rice plants. The research method uses a completely randomized design (CRD) consisting of 5 treatments consisting of $A$ $=$ control (1 liter of water), $B=1$ liter of water $+101 / \mathrm{ml}$ Beauvaria bassiana spores, $C=1$ liter of water $+102 / \mathrm{ml}$ Beauvaria bassiana spores , $D=1$ liter of water $+104 / \mathrm{ml}$ Beauvaria bassiana spores, $\mathrm{E}=1$ liter of water $+106 / \mathrm{ml}$ Beauvaria bassiana spores. The treatment was repeated as many as 6 replications so that there were 30 experimental units. The results showed that the treatment of 1 liter of water $+106 \mathrm{ml}$ of Beauvaria bassiana spores resulted in the highest mortality of chocolate bar and had a significant effect with other treatments.
\end{abstract}

Keywords : Plant pests, Brown stem slope, Biological agents, Beauvaria bassiana

\section{PENDAHULUAN}

Tanaman padi merupakan

komoditas strategis yang tetap mendapat

prioritas penanganan dalam pembangunan

pertanian di Indonesia, padi menjadi salah

satu sumber karbohidrat yang dikonsumsi

sebagian besar penduduk di dunia, http://ejournal.urindo.ac.id/index.php/pertanian dikarenakan padi termasuk jenis tanaman yang menghasilkan bahan pangan. Kandungan gizi yang tinggi menjadikan kebutuhan beras setiap tahun semakin bertambah seiring dengan laju pertumbuhan penduduk, sehingga tanaman padi sebagai salah satu bidang

Article History : 
pertanian yang digalakan di wilayah Indonesia. Produksi beras mengalami penurunan, tetapi permintaan konsumsi beras meningkat.

Serangan hama merupakan masalah yang sering dihadapi dalam budidaya tanaman padi. Salah satu hama penting adalah wereng batang coklat (WBC). Serangan hama ini dapat menurunkan produksi maupun mutu bahkan menyebabkan panen gagal. Pada tahun 1960 an, hama ini berstatus sebagai hama potensial dan semakin meluas mulai di awal tahun 1969 sehingga statusnya berubah menjadi hama utama tanaman padi. Perubahan ekosistem dan cara budidaya tanaman menyebabkan populasi WBC semakin meningkat. Hama ini kembali menyerang tanaman padi pada tahun 2010 sehingga menyebabkan puso yang merusak 23.187 ha persawahan hingga akhirnya tahun 2014 wereng WBC menyebabkan kerusakan pada berbagai sentra produksi padi [1].

Pada saat ini insektisida masih menjadi unggulan untuk mengendalikan hama, sehingga untuk memperoleh hasil yang optimal diperlukan strategi pengendalian hama yang optimal yaitu pengendalian hama terpadu (PHT). Sistem ini lebih menonjolkan keterpaduan penggunaan beberapa komponen pengendalian secara alami, seperti musuh alami (parasitoid, predator, dan patogen serangga), pengendalian secara fisik dan mekanik, pengendalian dengan menanam varietas tahan dan insektisida nabati. Cendawan entomopatogen merupakan salah satu jenis agen hayati untuk mengendalikan hama tanaman. Salah satu cendawan entomopatogen yang sangat potensial untuk mengendalikan serangga hama adalah Beauveria bassiana (Balsamo) Vuillemin. Cendawan ini merupakan agen hayati yang sangat efektif mengendalikan sejumlah spesies serangga hama [2]. Namun demikian, tercatat lebih dari 200 jenis serangga yang dapat diinfeksi jamur ini yaitu whiteflies, aphids, belalang, rayap, Colorado potato beetle, Mexican bean beetle, Japanese beetle, Bboil weevil, Cereal leaf beetle, Bark beetle, lygus bugs, Semut api, penggerek jagung Eropa, codling moth, dan Douglas fir tussock moth, jangkrik dan aphid [3].

Beberapa jenis Beauveria menghasilkan metabolit sekunder seperti bassianin, bassiacridin, beauvericin, bassianolide, beauverolides, tenellin dan oosporein yang mampu melumpuhkan dan mematikan serangga [4]. Formula dan produk $B$. bassiana sudah banyak dikembangkan antara lain formula dalam bentuk butiran, granula yang mudah larut di dalam air serta formula bentuk gel. Tujuan penelitian ini untuk mengetahui efektivitas $B$. bassiana sebagai insektisida hayati terhadap mortalitas wereng batang coklat pada tanaman padi. 
Keunggulan

Beauveria

bassiana sebagai agen hayati adalah

selektif terhadap serangga sasaran

sehingga tidak membahayakan serangga

lain bukan sasaran (predator, parasitoid, serangga penyerbuk, dan serangga berguna lebah madu), tidak meninggalkan residu beracun pada hasil pertanian, dalam tanah maupun pada aliran air alami, tidak menyebabkan keracunan pada tanaman, serta mudah diproduksi dengan teknik sederhana.

\section{METODE}

\section{Bahan dan Alat}

Bahan yang di gunakan adalah tanaman padi varietas pelita, cendawan biakan $B$. bassiana, dan wereng batang coklat.

\section{Rancangan Penelitian}

Rancangan penelitian yang digunakan adalah Rancangan Acak Lengkap (RAL) yang terdiri dari 5 perlakuan dengan 6 kali ulangan. Perlakuan tersebut yaitu $A=$ 1 liter air (kontrol), B =1 liter air $+10^{1} / \mathrm{ml}$ spora $B$. bassiana, $C=1$ liter air $+10^{2} / \mathrm{ml}$ spora $B$. bassiana, $\mathrm{D}=1$ liter air $+10^{4} / \mathrm{ml}$ spora $B$. bassiana, $\mathrm{E}=1$ liter air $+10^{6} / \mathrm{ml}$ spora B. bassiana.

\section{Cara Kerja}

\section{Pembuatan Agensia Hayati B. bassiana}

Biakan B. bassiana dilarutkan dalam air (100 gram/liter air), kemudian diaduk sampai semua spora terlepas dari media kemudian larutan disaring untuk membersihkan ampas. Larutan hasil penyaringan tersebut sebagai perlakuan $\mathrm{E}$ yaitu kerapatan spora $10^{6} / \mathrm{ml}$. untuk membuat larutan dengan kerapatan spora $10^{4} / \mathrm{ml}$ ialah dengan cara mengambil $10 \mathrm{ml}$ larutan B. bassiana yang kerapatan sporanya $10^{6} / \mathrm{ml}$ untuk dicampur dengan air sebanyak 1 liter, kemudian diaduk sebagai perlakuan D. Setelah larutan dengan kerapan spora $10^{4} / \mathrm{ml}$ tersedia, selanjutnya membuat larutan dengan kerapatan sporanya $10^{2} / \mathrm{ml}$, yaitu dengan cara mengambil $10 \mathrm{ml}$ larutan yang kerapatan sporanya $10^{4} / \mathrm{ml}$ untuk dilarutkan dengan 1 liter air sebagai perlakuan C sedangkan untuk membuat larutan berkerapatan spora $10^{1} / \mathrm{ml}$ ialah dengan mengambil $100 \mathrm{ml}$ larutan spora $10^{2} / \mathrm{ml}$ dicampur dengan $900 \mathrm{ml}$ air sebagai perlakuan B.

\section{Serangga Uji}

Wereng batang coklat dikembangbiakkan mulai instar 1 setalah sampai instar 3, wereng diambil dari rumpun padi tempat pembiakan, kemudian dipindahkan ke dalam tanaman perlakuan sebanyak 10 ekor/perlakuan. Tiga hari kemudian dilakukan aplikasi B. bassiana.

\section{Tanaman Uji}

Varietas padi yang digunakan dalam penelitian ialah Pelita. Benih padi direndam dalam air selama 24 jam, lalu diangkat dan diperam selama 48 jam atau sampai benih berkecambah, benih yang telah berkecambah kemudian disemai ke 


\section{Jurnal IImiah Respati}

tanah yang telah disiapkan. Penanaman dilakukan setelah bibit padi berumur 1 minggu ke dalam polibag yang telah disiapkan sebelumnya. Setiap polibag berisi 3 bibit padi. Setelah tanaman padi berumur 20 hari, maka tanaman telah siap untuk digunakan dalam pengujian.

\section{Aplikasi Agensia Hayati B. bassiana}

Tanaman padi yang berumur 20 hari dikurung dengan menggunakan kurungan serangga, kemudian diinokulasi wereng batang coklat kedalam pertanaman. Setelah wereng 3 hari berada di dalam pertanaman baru kemudian dilakukan penyemprotan larutan $B$. bassiana sebanyak 1 kali pada sore hari.

\section{Pengamatan}

Pengamatan dilakukan sebanyak 5 (lima) kali, interval waktu 2 hari dengan menghitung jumlah wereng yang mati. Kemudian menghitung mortalitas wereng batang coklat dengan menggunakan rumus sebagai berikut:

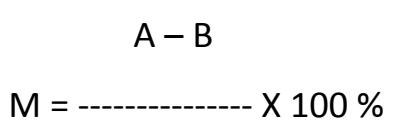

\section{A}

Keterrangan :

$\mathrm{M}=$ Mortalitas

A = Populasi Sebelum Aplikasi

B = Populasi Setelah Aplikasi

\section{HASIL DAN PEMBAHASAN}

Berdasarkan analisis sidik ragam diketahui bahwa pemberian B. bassiana berpengaruh nyata terhadap mortalitas WBC pada 4 HSA sampai 10 HSA sedangkan pada 2 HSA, B. bassiana belum menunjukkan pengaruh terhadap mortalitas WBC seperti yang disajikan pada Tabel 1. Pada 4 HSA sampai 10 HSA, perlakuan 1 liter air $+10^{6} / \mathrm{ml}$ spora $B$. bassiana menghasilkan mortalitas WBC yang paling tinggi dan berbeda nyata terhadap perlakuan lainnya khususnya pada 8 HSA yaitu 41,2\%. Perlakuan tersebut menghasilkan mortalitas WBC yang semakin meningkat hingga 8 HSA namun terjadi penurunan mortalitas pada 10 HSA yang hasilnya justru mendekati mortalitas wereng batang coklat pada 4 HSA.

Mekanisme serangan B. bassiana terhadap serangga dimulai dengan munculnya konidia pada integumen. Hifa jamur ini akan mengeluarkan enzim lipolitik, proteolitik dan khitinase yang menghidrolisis integumen serangga. Bahan penyusun integumen serangga adalah protein dan khitin. B. bassiana akan melepaskan beauverisin yang bersifat racun dan mampu merusak jaringan tubuh serangga. Serangga tersebut akan mati pada hari kedua dan seluruh bagian tubuhnya akan ditumbuhi miselia jamur. Serangga yang terinfeksi $B$. bassiana akan menunjukkan gejala awal yaitu tidak makan, gerakan lemah, serta bergerak tidak menentu atau kehilangan gerak [5]. 
Tabel 1. Pengaruh B. Bassiana terhadap mortalitas wereng batang coklat

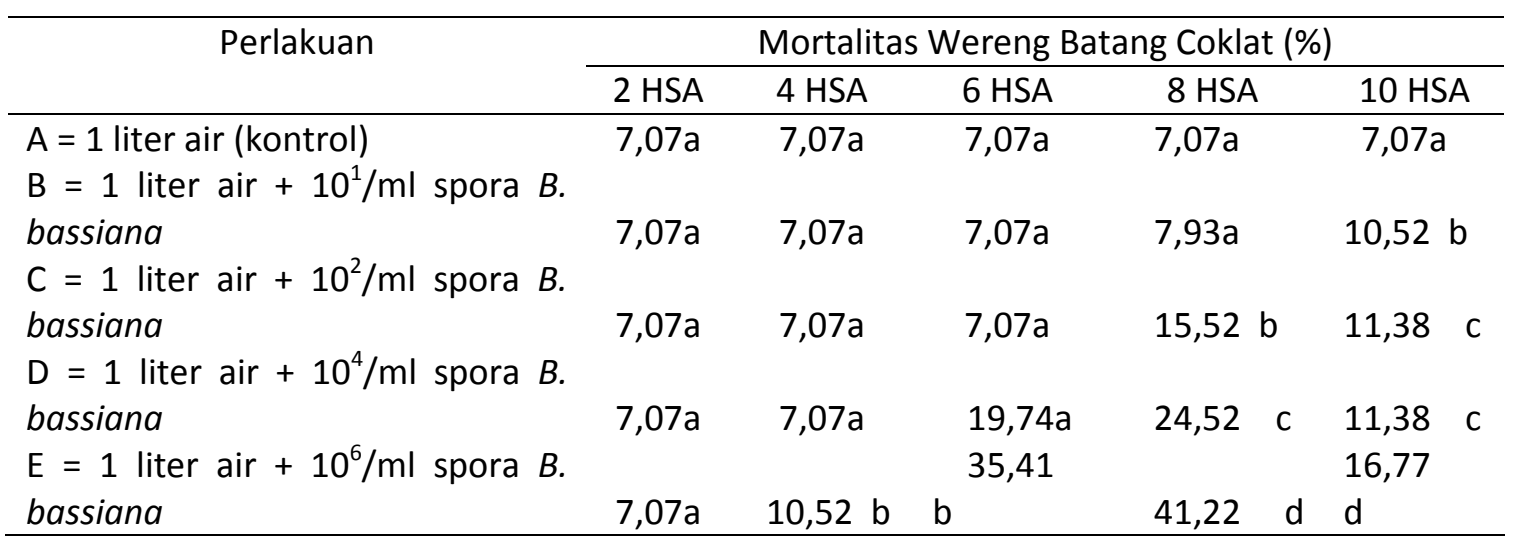

Keterangan : angka-angka yang diikuti huruf yang sama pada kolom yang sama, berarti tidak berbeda nyata menurut uji BNT pada taraf $5 \%$

Frekuensi aplikasi jamur dilakukan secara berulang agar pengendalian hama lebih optimal [6]. Aplikasi setiap 1 minggu mampu menekan pertumbuhan dan perkembangan hama sehingga tanaman dapat tumbuh dan berkembang secara maksimal. Selain itu, kerapatan spora juga dapat meningkat sehingga spora yang menempel juga semakin banyak yang mengakibatkan hama tersebut mati [7].

Namun demikian, secara umum pemberian B. bassiana dengan perlakuan sampai $10^{6} / \mathrm{ml}$ spora B. bassiana belum mampu menghasilkan mortalitas wereng batang coklat hingga 50\%. Dosis tertinggi pada penelitian ini hanya mampu menghasilkan mortalitas WBC sebesar 41,2\%. Biopestisida uji terhadap mortalitas N. viridula menunjukkan bahwa konsentrasi cendawan B. bassiana mempengaruhi stadia perkembangan nimfa dan imago N. viridula, akan tetapi tidak berpengaruh terhadap mortalitas nimfa dan imago. Semakin tinggi konsentrasi $B$. bassiana maka semakin tinggi pula mortalitas dan semakin lanjut stadia perkembangan serangga maka semakin rendah mortalitas serangga [5] .

Jamur entomopatogen memasuki inang dari bagian luar melalui kontak dengan integument serangga [8]. Selanjutnya spora infektif akan melekat pada kutikula serangga inang yang peka, berkecambah membentuk tabung kecambah menembus kutikula serangga inang menuju ke hemocoel. Di dalam hemocoel jamur akan tumbuh dan berkembang dengan membentuk pertunasan tubuh hifa sampai seluruh ruang hemocoel terisi oleh massa hifa dan serangga inang mati [9]. Dengan demikian serangga tidak mampu merusak tanaman sehingga tanaman dapat melakukan metabolisme secara optimal dan fase pertumbuhan tanaman tidak terganggu. 


\section{SIMPULAN}

Agen hayati B. bassiana berpengaruh nyata terhadap mortalitas wereng batang coklat. Konsentrasi formula B. bassiana 1 liter air $+10^{6} / \mathrm{ml}$ spora menghasilkan mortalitas wereng batang coklat paling tinggi pada 8 hari setelah aplikasi yaitu $41,22 \%$ sedangkan mortalitas wereng batang coklat paling rendah adalah kontrol yaitu $7,07 \%$.

\section{DAFTAR PUSTAKA}

[1] Khoiroh F, Isnawati dan F. Ulfi. 2014. Patogenitas Cendawan Entomopatogen (Lecanicillium lecanii) sebagai Bioinsektisida untuk Pengendalian Hama Wereng Batang Coklat secara in Vivo. Lentera Bio. 3(2): 115-121.

[2] Soetopo, D. dan I.G.A.A. Indrayani. 2007. Status Teknologi dan Prospek Beauveria bassiana untuk Pengendalian Serangga Hama Tanaman Perkebunan Yang Ramah Lingkungan . Perspektif. 6(1): 29-46.

[3] Wahyono, T.E. dan Wiratno. 2014. Bio Insektisida Beauveria bassiana Produk Komersil yang Berdaya Saing Tinggi dan Ramah Lingkungan. Prinsipprinsip dan teknologi pertanian organik. Badan Litbang Pertanian. 2014. pp. 83-87.

[4] Quesada-Moraga, E. \& Vey, A. 2004. Bassiacridin, a Protein Toxic for Locusts Secreted by The
Entomopathogenic Fungus Beauveria bassiana. Mycological Research. 108: 441-452.

[5] Hasnah, S., dan S. Husin. 2012. Keefektifan Cendawan Beauveria Bassiana Vuill. terhadap Mortalitas Kepik Hijau Nezara Viridula L. pada Stadia Nimfa dan Imago. J. Floratek.7: 13-24.

[6] Prayogo, Y. dan Suharsono. 2005. Optimalisasi Pengendalian Hama Pengisap Polong Kedelai (Riptortus linearis) Dengan Cendawan Entomopatogen Verticillium lecanii. Jurnal Litbang Pertanian. 24(4): 123130.

[7] Feron, P. 1981. Pest Control by the fungi Beauveria and Metharizium. in H.D. Burges. (Ed.), Microbial Control of Pest and Plant Diseases. New York, Academic Press. 465-482.

[8] Huffaker, C.B. dan P.S. Messenger. 1976. Theory and Practice of Biological Control. Diterjemahkan oleh Soeprapto M. 1989. Teori dan Praktek Pengendalian Biologis. Universitas Indonesia Press.

[9] Purnomo, H. 2005. Patogen Serangga. (Online). (http://www.patogen Serangga. pdf). Diakses 17 Maret 2017. 